\title{
O GOLEM NA ERA DA REPRODUTIBILIDADE TÉCNICA: APARATO CINEMATOGRÁFICO, HOMEM MODERNO E REPRESENTAÇÃO
}

\author{
Isabella C. Stangherlin Santucci \\ Universidade Estadual de Campinas
}

\begin{abstract}
Resumo: Aproximando Walter Benjamin ao movimento expressionista em sua forma fílmica e em sua postura subversiva, o presente artigo se propõe a pensar na figura do autômato enquanto alegoria na era da reprodutibilidade técnica. Destarte, partindo do ideal expressionista enquanto técnica e enredo cinematográficos e atravessando as Teses benjaminianas "Sobre o Conceito de História", bem como as diversas ideias contidas na obra do filósofo alemão acerca da obra de arte no século XX, veremos o Golem, personagem místico da tradição judaica representado pela figura de um ser gigante feito a partir de matéria inanimada, adquirir vida neste texto-tela. Vida esta que vem interromper o curso de uma História que se quis contínua ao relatar apenas a história dos vencedores, isto é, dos detentores de um poder político e/ou social, e ao ignorar a história dos vencidos, isto é, dos subjugados, dos até então obedientes. E tal irrupção não deverá ser somente obra de um ser mítico, mas também obra do homem enquanto proletário no sistema capitalista e da cinematografia enquanto aparato e representação.
\end{abstract}

Palavras-chave: O Golem. Walter Benjamin. Expressionismo Alemão. Literatura. Cinema.

O chapéu do burguês está voando de sua aguda cabeça, em todos os ares está ecoando a gritaria.

[Jakob van Hoddis, “Fim do Mundo”]

De acordo com Ismail Xavier, em sua obra $O$ Discurso cinematográfico: $a$ opacidade e a transparência (1977), se há um traço em comum que perpassa as diversas Vanguardas Europeias do século XX, este é a oposição a uma tradição clássica que concebe a arte como representação (mimese), isto é, como imitação. A proposta dos "ismos" será, portanto, de conceber a atividade artística como criação de um objeto autônomo, regido por suas próprias leis de organização. 
No entanto, nota o crítico (1977), tal oposição não qualifica as vanguardas como antirrealistas. Estas são, antes, concepções e visões específicas da realidade, distintas daquela que impulsionou o projeto realista do século XIX e, desta forma, acabaram por romper com certas convenções e técnicas próprias a esse projeto de representação.

Porém, uma das vanguardas, dada a "artificialidade" de seus métodos de representação, e a metafísica através deles proposta, principalmente no campo cinematográfico, seria alvo da crítica tanto dos variados defensores do realismo, como dos outros artistas e teóricos das diferentes formas de expressão artística das vanguardas: o Expressionismo.

Apesar de ter como período fértil a segunda década do século XX, o Expressionismo, segundo Gilberto Mendonça Teles (1972), pode ser dividido cronologicamente em três fases: os pré-expressionistas da pintura da última década do século XIX e primeira do XX; o expressionismo propriamente dito, o qual abrange o período que se estende de 1910 a 1920, e o qual, motivado pela Primeira Grande Guerra Mundial, atinge seu ápice nos quesitos produção e reprodução; e, por fim, a fase que corresponde ao período da república de Weimar e que tem seu término em torno de 1933, quando da ascensão de Hitler ao poder.

Assim, concentrando sua atividade artística em meio a períodos conturbados histórica, política e socialmente, o expressionismo irá contra a concepção de um mundo contínuo e claro. Para tanto, abrirá brechas nessa textura com fins a recuperar uma uma noção de experiência na qual os sentidos reinstaurem, como afirmou o pintor August Macke (1912 apud Xavier, 1977, p. 85), "a ponte entre o incompreensível e o compreensível”, buscando, então, em cada objeto, não sua realidade exterior, ou seja, o objeto visível, mas o além atrás de sua presença enquanto matéria, seu espírito vivo, libertando, em resumo, o olhar artístico dos estímulos apenas imediatos.

Serão marcas do movimento, destarte, as distorções e os jogos de sombra, uma vez que estes quebram a continuidade do espaço ao introduzir marcas do invisível. Ou seja, como constitui a presença mais nítida da forma pura, a sombra será capaz de "desnudar" o mundo visível e de recuperar sua verdadeira essência, sem a imposição ilusória da textura material.

Num sentido amplo, portanto, o expressionismo caracterizará toda arte criada sob o impacto da expressão da vida interior, das imagens encontradas no âmago de um ser. E mais especificamente, a prática de um idealismo platônico, a busca de soluções metafísicas e a noção de que há uma essência por trás da forma caracterizarão o movimento como uma 
resposta ao pensamento positivo que, em harmonia com o que se chamou de progresso tecnológico e material, havia deixado a essência humana se perder.

Não à toa, em postura de revolta, escreveria Kasimir Edschmid, em 1917, o único e tardio manifesto expressionista (1918 apud Teles, 1972, p. 83). Nele declararia o escritor a supranacionalidade do expressionismo, isto é, sua pertença à Humanidade, não a uma ou outra nação. Entretanto, graças à oposição ao positivismo e ao naturalismo e graças à preocupação metafísico-religiosa que atribui à obra de arte, o movimento correspondeu a um estado de espírito tipicamente alemão.

Como uma espécie de "barroco extemporâneo", o expressionismo trará consigo, dessa forma, o homem alemão, dito europeu, descontente com a realidade objetiva e desejoso por encontrar na essência interior de sua vida - e dos objetos que o rodeavam - sua salvação. Logo, constatada a inércia do sentimento burguês que até então imperava, este homem não mais deverá ser, diante da arte, um indivíduo ligado à moral, à família, à sociedade, à obrigação e à convenção, já que essas ligações deixariam opacas as imagens do humano. Deverá, sim, e por outro lado, tornar-se apenas homem, seja o mais grandioso ou o mais humilhado deles. Não existirão

\footnotetext{
mais histórias nupciais, tragédias surgidas do conflito das convenções e com a busca da liberdade, peças do meio ambiente (milieu), chefes rígidos, oficiais ociosos, marionetes ${ }^{1}$ que, penduradas nos arames das concepções psicológicas do mundo, brincam com leis, pontos de vista, erros e vícios dessa sociedade feita e construída pelos homens (1918 apud TELES, 1972, p. 83).
}

Em suma, caberá à arte o papel de revelar uma realidade que não deveria ser percebida em diferentes planos, psíquico ou físico, por exemplo, uma vez que a própria - e única - realidade era a expressão - a expressão de uma essência, até então oculta, que emanava dos próprios elementos e a qual o artista não podia controlar. E se essa essência interior fazia parte de um mundo obscuro e alógico, relacionando-se, nesse ponto, com o universo onírico e mítico, também seria alógica e obscura a expressão, contrapondo o 'equilíbrio' abstrato resultante do desequilíbrio de cada elemento da obra ao conhecido equilíbrio dos clássicos.

1 Grifo meu. 
Do exposto, não surpreende o fato de que o expressionismo tenha sido alvo da crítica dos realistas. Contudo, surpreende o fato de que ele tenha despertado, de uma certa forma, como barroco extemporâneo, a atenção de um filósofo judeu entre os anos de 1916 e 1925.

Walter Benjamin mergulharia, então, em seu trabalho Origem do drama barroco alemão, uma análise de tragédias alemãs do século XVII jamais encenadas, ou, como colocou Asja Lacis (1971 apud Bretas, 2008, p.149), uma análise da literatura morta. Em resposta a essa colocação, também proferida por outros teóricos e pesquisadores, Benjamin (1924) esclarecerá sua intenção apontando que a pesquisa do drama barroco não deveria se restringir à academia, uma vez que colocaria em pauta, por ser redigida entre a eclosão da Primeira Grande Guerra e a proclamação da República de Weimar, problemas atuais, principalmente os relacionados à situação sociopolítica da Alemanha do século XX.

Aparentemente incompreensível, neste momento, seu Trauerspiel-Buch assumirá uma postura denunciativa, no âmbito intelectual e político, evidentemente contrária ao cânone neokantiano defendido pela Escola de Marburg. Mas sua escolha pelo Trauerspiel [Drama], como bem ressalta Bretas (2008, p. 151), teria sido determinada muito mais pela reavaliação da literatura barroca pelo Expressionismo alemão. Embora criticasse a empatia como método para o conhecimento historiográfico, Benjamin (1984 apud Bretas, 2008, p. 151) admite: "Nenhuma sensibilidade artística teve tantas afinidades com a do Barroco, em sua busca de expressão [...], como a que caracteriza nossos dias”. Ora, essas afinidades poderiam ser encontradas não apenas num plano externo, considerando-se a violência belicista que marcara tanto o século XVII quanto o XX, como num plano interno, caracterizado pela atmosfera de luto, desespero, melancolia e angústia.

Assim, se na visão expressionista todo aspecto que até então era considerado repugnante, feio e proibido na vida, como a violência e a morte, pôde alcançar o protesto através da expressão artística, revelando-se como parte indissociável da realidade, em Benjamin não seria diferente. Ainda de acordo com Bretas (2008), ao se voltar para uma apreciação "redentora" da dimensão onírica em suas variadas expressões, o filósofo buscará a outra possibilidade, o belo oculto, na imagem do horrendo, como destaca em sua observação em Haxixe (apud Bretas, 2008, p. 152): "De súbito, compreendi por que [...] a feiura poderia valer como o verdadeiro reservatório do belo, ou melhor, como o seu cofre de tesouros, o veio cavado na montanha de onde se extrai o ouro recôndito do belo, cintilando por entre as rugas, olhares e feições". 
As "afinidades eletivas" do expressionismo com o Barroco alemão - e com Benjamin -, todavia, não estão ligadas apenas ao período histórico-político vivido pela nação germânica. Ressalta Bretas (2008, p. 154) que o repúdio à estética clássica e aos cânones, a contradição entre o desejo de expansão criativa e a virtual impossibilidade de se romper totalmente os padrões, a experimentação formal, a vasta utilização de imagens, a valorização da expressão e, por outro lado, o impasse da incomunicabilidade, a crença no além-dohomem, o super-homem (Übermensch), o conflito com a autoridade institucional e a reabilitação da alegoria são pontos de contato entre os dois movimentos.

Detenhamo-nos nesse último ponto de contato, a alegoria. Segundo Jeanne-Marie Gagnebin (1994, apud Salles, 2005, p.16) a alegoria em Benjamin é vista como a reabilitação da temporalidade e da historicidade, opondo-se, assim, ao ideal de eternidade encarnado pelo símbolo. Na mesma linha, e de encontro ao filósofo, o pensamento de Ismail Xavier, em seu artigo "A alegoria histórica", buscaria definir a noção de alegoria:

Da tradição clássica herdamos a noção de alegoria - etimologicamente allos (outro)
+ agoreuein (falar em lugar público) - como um tipo de enunciação na qual alguém
diz algo, mas quer dizer algo diferente, ou manifesta algo para aludir a uma outra
coisa. Tal definição, entretanto, é bastante genérica. Ela identifica, de forma
preliminar, a alegoria entre outras figuras de linguagem sistematizadas pelos
retóricos antigos, e sua utilidade na discussão contemporânea vem de um elemento
essencial implícito nessa acepção genérica, ou seja, a ideia de uma lacuna entre o
espírito (significado) e a letra (palavra). Vale já, nessa definição ampla, a concepção
de que um enunciado ou uma imagem aponta para um significado oculto ou
disfarçado, além do conteúdo aparente. Encontramos aqui a ideia de que as
linguagens mobilizadas na vida social são sistemas transparentes, implicando
convenções e processos contextualizados que efetuam a mediação entre palavras (ou
imagens) e a experiência vivida. (2005 apud SALLES, 2005, p. 16)

Ora, torna-se evidente, nessa noção, a aproximação entre Benjamin, sua alegoria e o movimento expressionista, já que por meio dela há sempre um "por trás" de um enunciado ou de uma imagem, revestidos sempre por texturas e convenções. Logo, de acordo com Willi Bolle (1994 apud Salles, 2005, p. 18), a figura alegórica, para ambos movimentos, traria consigo a imagem de um desejo ou utopia, uma imagem onírica e fantasmagórica, aproximando-se, dessa forma, do posterior conceito surrealista de sonho.

Enfim, partindo-se das afinidades acima citadas, pode-se afirmar que o livro do Barroco, por seu pathos, é uma obra "expressionista", dado que o expressionismo, aqui, vêm de encontro a um modo de agir e pensar tipicamente alemães. Dessa maneira, tal denominação atribuída a sua obra só pode ser legítima se referida à atitude, e não à filiação de 
Walter Benjamin ao movimento expressionista, fato que nunca ocorreu. Apesar de ter contato com alguns membros do Cabaré Neopatético (Neopathetisches Kabarett), sua identificação com o grupo seria limitada, preferindo, como destacou Scholem (1989 apud Bretas, 2008, p. 155), "a imoderação dos surrealistas" à "pretensão estudada" e os traços de "blefe e sinceridade" da literatura expressionista.

No entanto, conta-nos Scholem (1989 apud Bretas, 2008, p. 155), “[Benjamin] nutria grande admiração por algumas fases da pintura expressionista de Kandinsky, Marc Chagall e Paul Klee". E, como vimos, sua atração ao movimento se daria também por uma questão política, já que, como atenta Furness (1990 apud Bretas, 2008, p. 157), o expressionismo alemão vinculou-se aos movimentos de esquerda, sobretudo o Comunismo, no anseio por uma nova sociedade, um novo homem, um novo objetivo - assim como o Nacional-socialismo, de outro lado. O termo Aufbruch (partida, surgimento, recomeço, despertar), traduziria bem, portanto, a expectativa de transição, a "decadência produtiva", apontada por Benjamin em seu livro do Barroco, preparatória de uma nova era, uma era em que o expressionismo seria dela como que o mensageiro de Kafka do conto "Uma mensagem Imperial". Como observa Kracauer (1988 apud Bretas, 2008, p. 157)., "no sentido pleno em que foi usado, [Aufbruch] significava 'saída do mundo sombrio de ontem em direção a um amanhã construído com base em concepções revolucionárias"”.

Não apenas o expressionismo, mas também Benjamin, aqui, deverão anunciar o novo, o despertar que vem ao lado das sobras da guerra. Guerra essa que colocou, para Benjamin, como sustenta Chaves (1998 apud Bretas, 2008, p. 164), a questão ou do mito ou da história. 'Escolher o 'mito' significaria escolher a barbárie e correr, com o Zaratustra na mochila, para os campos de batalha. Escolher a 'história' significaria encontrar um instrumento de crítica, cortante o suficiente para contrapor-se às forças do mito". Não restam dúvidas, se pensarmos em sua última obra, as teses Sobre o conceito de história, de que Benjamin teria escolhido a história, uma história diferente da que foi contada, como arma de seu tempo.

Der Historismus gipfelt von rechtswegen in der Universalgeschichte [O Historicismo culmina de direito na história universal] (Benjamin, 2007, p. 138). Com esta afirmação, não menos universalizante, porém aqui contextualizada, inicia Walter Benjamin sua décima sétima tese "Sobre o Conceito de História". Escritas no exílio, sob o choque do pacto de agosto de 1939 entre Hitler e Stálin, suas teses são ao mesmo tempo uma síntese de seu 
pensamento e um desabafo consciente. Mais uma vez a história dos vencedores seria contada; mais uma vez a narrativa épica dos heróis já consagrados se apresentaria (e seria vista) como a verdadeira e total expressão da História. No entanto, como no conhecido movimento daquele súdito (ou leitor) "sem esperança" que, paradoxal e complementarmente, "espera" do conto "Uma mensagem imperial" (1917) de Kafka, Benjamin propõe a tarefa emergencial de se "escovar a história a contrapelo" (Benjamin, 2005, p. 70). Não viveria, (in)felizmente, para acompanhar as catástrofes que se seguiram no desenrolar da Segunda Guerra Mundial, bem como para observar "a fraca força messiânica" (Benjamin, 2005, p. 48) dos vencidos emergir sob a forma de rumores e testemunhos.

Assim, nota Benjamin em suas teses (2005, p. 65), que a associação do tempo com a dominação (ou conquista) do "inimigo que não tem cessado de vencer", é uma constante na historiografia tradicional, ou seja, historicista, e culmina sempre na formação de uma imagem “eterna" (pretensamente eterna) do passado. A História Universal apresentada pelos vencedores, propondo-se a definir um universo, seja ele nacional, regional ou cósmico, dessa maneira, baseia-se sobre a exclusão de coisas e fatos que desejam ter voz mas que, por se relacionarem com o discurso do vencido, permanecem mudos. Entretanto, esse "por debaixo" da narrativa historicista está presente, ameaçando constantemente a pretensa representação do "todo".

Em oposição ao Historicismo, portanto, surgiria o que Benjamin definiu por Materialismo Histórico. E caberia a seu historiador - o historiador materialista - a função de abrir as lacunas deixadas pela história oficial, aos lamentos ignorados ou esquecidos. Contudo, como descreve Benjamin (2005, p.62), o passado nunca poderá ser possuído totalmente, uma vez que ele não está à nossa disposição, como o Historicismo resume na passagem "A verdade não nos escapará" de Keller. A verdadeira imagem do passado passa "célere e furtiva" (Benjamin, 2005, p. 62). Apenas quando lampeja num instante de perigo, que é o instante de sua recognoscibilidade, quando ameaçada em se transformar em mais "um instrumento da classe dominante" ou desaparecer num "presente que não se reconhece como nela visado" (Benjamin, 2005, p. 62), esta imagem poderá ser capturada. A essa imagem Benjamin dá a alcunha de "dialética".

Melhor explicando, Benjamin nos diz que não é que o passado lance sua luz sobre o presente, ou que este lance sua luz sobre o passado, uma vez que essas relações seriam apenas 
temporais ${ }^{2}$. Mas, sim, a "imagem dialética" seria o resultado do encontro do "ocorrido" (Gewesene), o elemento esquecido, recalcado, inconsciente do passado, com o "agora" (Jetzt) único, oportuno, o kairos, numa imagem já em germe na sua ideia de "constelação" desenvolvida na Origem do Drama Barroco Alemão, isto é, como bem elucidou Jeanne-Marie Gagnebin (informação verbal) ${ }^{3}$, “une formation visuelle et conceptuelle qui nous permet de donner un nom à une image qui, sans ce schème, resterait floue et ne pourrait être reconnue (comme on dit par exemple 'Cassiopée' pour désigner un ensemble d'étoiles dans le ciel)"”.

Emergindo apenas em certos momentos precisos, pois que "todas las cosas le suceden a uno precisamente, precisamente ahora" (Borges, 2007, p. 100), o "ocorrido", a imagem do passado precisa, então, ser paralisado. Em outras palavras, é preciso parar, suspender o tempo, e prestar atenção a esses elementos esquecidos e ao que eles podem nos dizer como imagem que são, pois apenas através deles o passado consegue interpelar o presente e exigir de nós, habitantes do presente, uma ação. É o que poderíamos chamar de "dialética em repouso" (Stillstand). Caso contrário, serão novamente perdidos e engolidos pelo esquecimento.

Esta relação dialética com o passado, de acordo com Benjamin, operaria num princípio cíclico, mas tendo em seu pensamento que ciclicidade não é repetição, já que "o ocorrido" irrompe num "agora" preciso, ou seja, num instante que difere de todos os outros. Pelo contrário, o efeito desse princípio é o de dissipar qualquer ideia de continuidade, de universalismo e de ordenação. Defende-se, aqui, o fragmento, a experiência única com o passado e a interrupção cíclica numa História que até então vinha se apresentando sob a imagem da verdade e da totalidade.

Interessante notar e não confundir o fato de que Benjamin nega a ideia de uma História Universal enquanto representação por estar esta sempre ligada ao discurso dos vencedores e jamais admitir interrupções e mudanças em seu curso, mas assume que o "tempo-de-agora" (Jesztzeit), enquanto modelo do tempo messiânico, resumindo em si a história de toda a humanidade, como que numa abreviação, coincidiria "com $a$ figura que a história da humanidade ocupa no universo" (Benjamin, 2005, p.138). Isto quer dizer que

\footnotetext{
${ }^{2}$ Cf. Seligmann-Silva, 1999, p. 228

3 Descrição fornecida por Jeanne-Marie Gagnebin em seminário apresentado durante a disciplina LT141Seminários Avançados Sobre Crítica, oferecida pelo Instituto de Estudos da Linguagem (IEL) da Universidade Estadual de Campinas (Unicamp) no primeiro semestre de 2011.

4 "uma formação visual e conceitual que nos permite dar um nome a uma imagem que, sem este esquema, ficaria vaga e não poderia ser reconhecida (como dizemos, por exemplo, 'Cassiopéia' para designar um conjunto de estrelas no céu)". (tradução nossa)
} 
teríamos diversas figuras da história humana, uma vez sabido que o tempo, para Benjamin, estava repleto de diversos "agoras". Para ele, estes "agoras", o "breve minuto de plena posesión de las formas" (1992 apud Löwy, 2002, p. 158), seriam a verdadeira história universal, a história universal da humanidade liberada, ou melhor, salva. Em suma, remetendo-nos ao conceito cristão de anakephalaiosis ou recapitulação, esse agora resume todos os momentos do passado e toda a tradição dos oprimidos, articulando-se, assim, como potência redentora e revolucionária no presente.

A história, para Benjamin, a partir do exposto, seria objeto de uma construção, cujo lugar não é formado por um tempo homogêneo, linear e vazio. Será contra a ideia, por conseguinte, de uma história representada como avanço cronológico aliada à representação do progresso do gênero humano.

Ora, é bem verdade que, lembra-nos Benjamin em suas teses X e XIII, a crença no progresso, principalmente por parte da socialdemocracia, estava neste momento atrelada somente ao progresso técnico, ou seja, à ideia de que a técnica, independentemente de seu uso e aplicações, significaria um avanço "essencialmente irresistível” (Benjamin, 2005, p. 116) da humanidade a caminho da libertação. Nietzsche (1988 apud Chaves, 1998, p. 23) fala dessa crença, que também é a crença numa ideia de processo universal, como uma espécie de "teologia camuflada", que outorgaria à ciência o que antes, na Idade Média, outorgava-se a Deus: "um tal modo de pensar acostumou os alemães a falarem de processo universal e a justificar o seu próprio tempo como o resultado necessário desse processo; um tal modo de pensar colocou a História como única soberana no lugar de outras forças do espírito como a arte e a religião".

A crença obstinada da política no progresso, sua confiança em sua "base de massa", e, por fim, sua submissão servil a um aparelho incontrolável seriam, dessa forma, três aspectos de uma única e mesma coisa. E não só na política, como também na economia, o conformismo se estabelecerá. Como afirma Benjamin (2005, p. 06), "não há nada que tenha corrompido tanto o operariado alemão quanto a crença de que ele nadava com a correnteza. Daí era só um passo até que a ilusão de que o trabalho fabril, que se inserisse no sulco do progresso técnico, representaria um feito político". Fica claro, então, que essa concepção positivista, destacando apenas as benesses da técnica e do progresso, ignoraria os retrocessos da sociedade, a qual teria seu membro revolucionário amputado. 
Evidencia-se, nessas ideias, a forte influência que a obra $O$ Capital, de Karl Marx, exerceu em Walter Benjamin. Segundo Marx (s/d apud Sousa, 2008, s/p), no trabalho manual, as diversas etapas da produção são ligadas continuamente, e o operário fabril, nessa linha de montagem, perde a capacidade de controle, tornando-se apenas uma peça autônoma e coisificada diante do aparato industrial. Em resumo, não seria o operário, diante da maquinaria, que utilizaria as condições de trabalho, mas estas que o utilizariam. Aprenderiam, assim, a coordenar o próprio movimento ao movimento constante e uniforme de um "autômato", aponta Benjamin (1987). Domesticando-se, adestrando-se às exigências da técnica na era moderna, transforma-se o ser humano, também, em autômato, um boneco mecânico que apenas repete os mesmos e vazios gestos da máquina, que perdeu toda experiência e toda memória ou, como diz Benjamin em O Narrador (1987), um homem destituído de sabedoria, e, portanto, incapaz de narrar uma história, de escutar ou dar conselhos, uma vez que não possui experiências (Erfahrung).

Do exposto, conseguimos visualizar os efeitos destrutivos que a tempestade do progresso trouxe à humanidade e à história. E também Benjamin, inspirado no quadro expressionista de Klee, “Angelus Novus", definiria, em sua nona tese, as consequências carregadas com o avanço da técnica e com historicismo propagado pelos vencedores:

\footnotetext{
Existe um quadro de Klee intitulado "Angelus Novus". Nele está representado um anjo, que parece estar a ponto de afastar-se de algo em que crava o seu olhar. Seus olhos estão arregalados, sua boca está aberta e suas asas estão estiradas. O anjo da história tem de parecer assim. Ele tem seu rosto voltado para o passado. Onde uma cadeia de eventos aparece diante de nós, ele enxerga uma única catástrofe, que sem cessar amontoa escombros sobre escombros e os arremessa a seus pés. Ele bem que gostaria de demorar-se, de despertar os mortos e juntar os destroços. Mas do paraíso sopra uma tempestade que se emaranhou em suas asas e é tão forte que o anjo não pode mais fechá-las. Essa tempestade o impele irresistivelmente para o futuro, para o qual dá as costas, enquanto o amontoado de escombros diante dele cresce até o céu. O que nós chamamos de progresso é essa tempestade. (BENJAMIN, 2005, p. 87)
}

Nesse ponto torna-se curioso o fato de que Benjamin, em 1936, tenha escrito o famoso texto "A obra de arte na era de sua reprodutibilidade técnica", no qual declara que um dos maiores aparatos técnicos desenvolvidos no século XX, o cinema, resultado do progresso alienante, ainda assim possua em sua essência uma espécie de força militante.

Acusado por Theodor Adorno de utopismo tecnológico (2006 apud Garcia, 2011, $\mathrm{s} / \mathrm{p}$ ), o qual, ao mesmo tempo em que fetichizava a técnica, ignorava seu alienante funcionamento social na realidade, Benjamin esperava, na verdade, colocar em evidência as 
consequências positivas de uma forma de percepção que se modificava com a tecnologia, sem, com isso, deixar de pensar nas indevidas apropriações por parte dos "vencedores".

Assim, inicia seu texto apontando as gigantescas transformações provocadas pela reprodução técnica da obra de arte, seja ela escrita ou composta por imagens, tais como o fato de que as produções artísticas poderiam ser colocadas em massa no mercado, atingindo, portanto, um maior público, ou o fato de que estas poderiam, agora, aparecer sob a forma de criações sempre novas, adquirindo a capacidade de ilustrar a vida cotidiana.

Em suma, afirma Benjamin (1987, p. 167), a reprodução técnica atingiria tal padrão de qualidade que não apenas poderia transformar as obras tradicionais, submetendo-as a profundas transformações, como conquistaria para si, especialmente em âmbito cinematográfico, um lugar próprio entre os procedimentos artísticos.

Todavia, nota o filósofo (1987 p. 167), o aqui e agora de uma obra de arte, isto é, sua existência única, estaria ausente mesmo na reprodução mais perfeita. E é nessa existência que se desdobra a história da obra, a qual compreende as transformações que, com a passagem do tempo, a obra sofreu em sua estrutura física, bem como as relações de propriedade em que ingressou. Os vestígios desta são o objeto de uma tradição, e sua reconstituição precisaria partir do local em que se encontrava a obra original; os vestígios daquela apenas podem ser investigados por meio de análises químicas ou físicas, também irrealizáveis numa reprodução.

Conclui-se, então, que o que se perde ao lado desse "aqui e agora" é a autenticidade de uma obra, ou seja, tudo aquilo que foi transmitido pela tradição desde sua origem, incluindo sua duração material, até o seu testemunho histórico, identificando, assim, um objeto como sendo aquele objeto, sempre igual e idêntico a si mesmo. Em especial no cinema, graças a certos procedimentos como a câmara lenta ou a ampliação, que se afastam completamente da ótica original, a técnica acabará por colocar a reprodução de um objeto em situações que seriam impossíveis para o próprio original, como a aproximação entre o indivíduo que observa e a obra, e que, por outro lado, desvalorizam cada vez mais um conceito de "existência única".

Desaparece para Benjamin, em resumo, diante da técnica e de suas novas formas de reprodução, a autoridade do objeto, seu peso tradicional dado através do que o filósofo define por aura. O declínio atual da aura, dessa maneira, estaria ligado à crescente difusão e intensidade dos movimentos das massas modernas, uma vez que estas, com sua tendência em 
fazer as coisas "ficarem mais próximas", tendem a superar o caráter único de um objeto ou fato por meio da reprodutibilidade, instaurando, para eles, uma existência serial.

Pode-se dizer, em outras palavras, que a obra de arte perde seu valor de culto, pois que a forma mais primitiva de sua inserção no contexto da tradição se dava através de cerimônias rituais e, posteriormente, de cerimônias religiosas. O valor único da obra de arte dita "autêntica", então, estaria sempre atrelado a um fundamento teológico, o qual definiria sua função. Com o advento da reprodutibilidade técnica, o valor de culto será substituído por um valor de exposição. Se antes, no ambiente ritualístico, as obras de arte não precisavam ser vistas, bastando que existissem em algum local secreto, agora, que adquiriram, com a técnica, uma função prática, elas deverão ser vistas. Melhor explico: a obra de arte substitui seu valor de culto por um valor de distração, o qual tem no cinema seu cenário privilegiado. E esse valor é fundamentalmente de ordem tátil, isto é, coíbe a contemplação e a associação de ideias por parte do espectador, que se encontra diante de uma tela, através do choque provocado pela mudança repentina de lugares, ângulos e imagens.

Para Benjamin (1987, p. 192), portanto, “o cinema é a forma de arte correspondente aos perigos existenciais mais intensos com os quais se confronta o homem contemporâneo", e essa correspondência é dada por um choque proposital. Digo isto porque, de acordo com o filósofo, um filme não é produto "de um só jato", mas, antes, efeito de uma montagem a partir de inúmeras imagens isoladas e sequências de imagens entre as quais o "montador" exerceria sua escolha. Entretanto, apesar de restar o choque depois desse trabalho de "catador de trapos", a finalidade última da montagem seria a perfeição, a ilusão de que o que se vê diante da tela é realidade "pura", sem qualquer resquício do corpo estranho da máquina. "A realidade, aparentemente depurada de qualquer intervenção técnica, acaba se revelando artificial, e a visão da realidade imediata não é mais que a visão de uma flor azul no jardim da técnica" (Benjamin, 1987, p. 186).

Ora, nesse ponto fica evidente a aproximação de Benjamin com o expressionismo, se não no que tange à técnica de montagem mais apropriada, pelo menos na crença de que a realidade que provém dos estímulos imediatos é artificial, e de que há sempre um "por trás". No entanto, não apenas no movimento expressionista a teoria de montagem de Benjamin encontraria respaldo. Também em Sergei Eisenstein, diretor que afirma, aponta Andrew (1989 apud Tomaim, 2004, p. 114), que "ver um filme é como ser sacudido por uma cadeia contínua de choques vindos de cada um dos vários elementos do espetáculo cinematográfíco, não 
apenas do enredo". Desta forma, para Eisenstein (2002, apud Tomain, 2004, p. 115), o cinema deve fazer, por meio da identidade, com que os espectadores saiam de si mesmos, ou seja, de sua condição como alienados.

Não teria o cinema, também para Benjamin, outra função. Ele, como obra de arte na era da reprodutibilidade técnica, ou melhor, como uma reprodução que se tornou arte, teria uma função social, e não ritual. E essa função seria a de criar um equilíbrio entre o homem e o aparelho. Assim, através dos seus grandes planos, de sua ênfase sobre pormenores ocultos de objetos familiares, de sua investigação dos ambientes mais vulgares, e, principalmente, através do ator, um homem comum, o cinema faria, por um lado, o espectador vislumbrar os condicionamentos que determinavam sua existência. Observando, então, a vitória do ator, que mesmo diante da luz dos refletores e das exigências dos microfones, em suma, de todo aparelho técnico, foi capaz de conservar sua dignidade humana, a maioria dos citadinos, submissos também a um aparelho que aliena sua humanidade a cada dia de trabalho, sente-se vingada.

Por outro lado, o cinema asseguraria um grande e insuspeitado espaço de liberdade ao espectador, abrindo a câmera, pela primeira vez, a experiência do inconsciente ótico. Isso quer dizer, segundo Benjamin, que os múltiplos aspectos que o aparelho poderia registrar da realidade se situariam em grande parte fora do espectro de uma percepção sensível dita "normal". Tornado o aquário "do exotismo e do passado" (Benjamin, 1995, p. 26), o dispositivo cinematográfico, apresentando em si as deformações, transformações, catástrofes e estereotipias sofridas pelo mundo visual, acabaria por influenciar positivamente o mundo das psicoses, alucinações e sonhos. Logo, diante da tecnicização que engendrou tensões e psicoses nas massas trabalhadoras, surgiria o cinema, fruto dessa mesma tecnicização, como uma espécie de imunização contra tais psicoses. Os filmes grotescos dos Estados Unidos, assim como os filmes de Disney seriam, portanto, uma terapia para o inconsciente.

Contudo, o que Benjamin espera que ocorra entre o espectador e o aparato cinematográfico, além da identidade e da liberdade proporcionadas, é sua utilização política. Como arte democrática controlada pelas massas e para as massas, o cinema permitiria a "revolução do proletariado", ou melhor, dos "vencidos" da história. Mas, confessa o filósofo (1987, p.180), essa utilização política teria que aguardar até que o cinema se libertasse de sua exploração pelo capitalismo, pois que o capital daria um caráter contrarrevolucionário às oportunidades revolucionárias imanentes ao aparato. Caráter este, em resumo, que estimularia 
o culto do estrelato e de seu complemento, o culto do público, além de incentivar a consciência corrupta das massas, a qual o fascismo pretende pôr no lugar de sua consciência de classe.

Na Europa Ocidental, por exemplo, a exploração capitalista do cinema impediria a concretização da aspiração do homem moderno em se ver reproduzido. Tal impedimento seria auxiliado, também, pelo desemprego, que excluiu grandes massas do processo produtivo, por meio do qual esta aspiração deveria emergir. Nessas circunstâncias, analisa Benjamin, a indústria cinematográfica teria interesse em estimular a participação das massas apenas através de especulações ambivalentes e concepções ilusórias. Mobilizaria, desta forma, um poderoso aparelho publicitário envolvido com a busca de novidades sobre a vida amorosa das estrelas, com concursos de beleza, com a venda de produtos, entre outros itens. Tudo isso com fins à corrupção e à falsificação, diria o filósofo alemão, do interesse original das massas pelo cinema, um interesse de classe.

Conclui seu texto, assim, profetizando que todo e qualquer esforço em se estetizar a política, como praticava o fascismo, ou a resposta a esse esforço, isto é, a politização da arte como praticava o comunismo, convergiria, mais cedo ou mais tarde, para um único ponto: a guerra. Mas, até aí, as massas seriam apenas autômatos a serviço da política, da economia e da sociedade imperantes.

E, como reforça Benjamin na primeira de suas teses "Sobre o conceito de história", não só as massas proletárias, mas a história, num sentido geral, encontraria na figura de um autômato sua representação:

\footnotetext{
Como se sabe, deve ter havido um autômato, construído de tal maneira que, a cada jogada de um enxadrista, ele respondia como uma contrajogada que lhe assegurava a vitória da partida. Diante do tabuleiro, que repousava sobre uma ampla mesa, sentava-se um boneco em trajes turcos, com um narguilé à boca. Um sistema de espelhos despertava a ilusão de que essa mesa de todos os lados era transparente. $\mathrm{Na}$ verdade, um anão corcunda, mestre no jogo de xadrez, estava sentado dentro dela e conduzia, por fios, a mão do boneco. Pode-se imaginar na filosofia uma contrapartida dessa aparelhagem. O boneco chamado "materialismo histórico" deve ganhar sempre. Ele pode medir-se, sem mais, com qualquer adversário, desde que tome a seu serviço a teologia, que, hoje, sabidamente, é pequena e feia e que, de toda maneira, não deve se deixar ver. (BENJAMIN, 2005, p. 41)
}

Segundo Michel Löwy (2002, p. 48), Benjamin sugere, através de "chamado", e não "se chamava", que o boneco materialismo histórico, este autômato, não era o "verdadeiro" materialismo histórico, mas assim era chamado pelos porta-vozes do marxismo, ou seja, os 
ideólogos da II e III Internacional. Na mão destes, percebe Benjamin, o materialismo histórico torna-se um método que enxergaria a história como uma espécie de máquina capaz de conduzir automaticamente 5 ao triunfo do socialismo e do proletariado, uma vez que o progresso econômico, as leis da indústria e o desenvolvimento das forças produtivas levariam o capitalismo à crise. Porém, bem destaca Löwy (2002, p. 48), esse autômato, esse boneco, não é capaz de ganhar a partida, aqui entendida como " interpretar correctamente la historia, luchar contra la visión de la historia de los opresores" e "vencer al propio enemigo histórico, las clases dominantes". Para ganhar, nota, o materialismo precisaria do auxílio da teologia, o anão oculto, velho e feio, pois que se encontra numa época dominada pelo racionalismo e pela incredulidade. E o que significaria, para Benjamin, a teologia?, questiona-se Löwy (2002, p. 51). A resposta vem nas outras teses: sem pretender uma reflexão sobre a natureza do Ser divino ou sobre as verdades eternas do mundo, a teologia deveria, com sua força explosiva, messiânica e revolucionária, através da rememoração, estar a serviço na luta dos oprimidos, reduzidos, como os próprios conceitos de história e materialismo histórico foram, à categoria de autômatos miseráveis.

Aproximemo-nos, então, dessa figura alegórica. Os autômatos, em geral, são composições mecânicas, muitas vezes rebuscadas, que têm por fim a mimese humana ou animal, mas que, por outro lado, são incapazes de raciocinar, podendo apenas reproduzir repetidamente certos movimentos. No folclore judaico, o autômato, ou golem, seria uma criatura animada antropomórfica feita a partir da lama, matéria inanimada, como Adão. Aliás, o termo "golem" ocorre na Bíblia, no Salmo 139:16, significando "forma sem forma". A Mishná utiliza o termo como significado de pessoa inculta. Já em hebraico moderno, "golem" significa burro, ou impotente, e constitui, por vezes, a metáfora do homem que, sob controle, não se permite pensar.

Teríamos em Benjamin, a partir do exposto, vários autômatos, ou golens: primeiramente a máquina, que, enquanto técnica e resultado do progresso na era moderna, revelava-se mecanicamente poderosa, mas intelectualmente inoperante; o próprio homem, automatizado e desumanizado pela máquina e pela política no ambiente de trabalho; a História, que até a revolução do materialismo histórico e da teologia, seria instrumento dos "vencedores" e incapaz, portanto, de revelar os instantes que foram recalcados no passado; e, em última instância, e, talvez por isso, mais importante, o cinema, o golem porque resultado

\footnotetext{
${ }^{5}$ Grifo nosso.
} 
da técnica, o golem porque instrumento do capitalismo e do fascismo, o golem porque ainda inerente a si teria o índice da identidade e da revolta de outros golens (o proletariado).

Pensemos, desta maneira, como Gilles Deleuze (1990 apud Nascimento, 2001, p. 308) ao considerar o cinema como psicomecânica, um automatismo espiritualizado, no que tange a seu conteúdo, seus temas, suas situações e seus personagens: ele "é o grande autômato espiritual que marca o exercício mais alto do pensamento, a maneira pela qual o pensamento pensa e se pensa a si mesmo, no fantástico esforço de uma autonomia" que traria uma nova e temível ordem.

Seria adequado, neste ponto, refletir novamente sobre o expressionismo, desta vez pelo viés cinematográfico. Observando, então, sua proposta de retirar o invólucro burguês e classista do homem, bem como de qualquer objeto que tivesse sua essência mascarada, o movimento expressionista se apresenta como adequado à proposta benjaminiana. Em outras palavras, aspirando à revelação da essência, do obscuro mundo de cada homem, o cinema expressionista não poderia senão tematizar essa condição automatizada a que as massas, a história e o próprio cinema eram submetidos.

Do ponto de vista técnico, desta forma, girariam a montagem, a iluminação, a profundidade, entre outros itens, em torno dessa proposta "reveladora". No caso da montagem, por exemplo, o papel a ela atribuído pelo expressionismo foi quase nulo, reduzindo a câmera ao mero papel de registro. Todavia, trabalhava arduamente com a préestilização e com os jogos de sombras, contrastando as zonas visíveis das invisíveis (as trevas), no que se denominou decupagem clara, em oposição ao realismo clássico e naturalista que, pretendendo-se o portador do "verdadeiro" real, como diria Benjamin, seria incapaz de ser verdadeiro, pois que excluía as infinitas e ocultas essências.

Para que fique mais claro o entendimento de todos estes conceitos, faz-se necessária, aqui, uma análise desse cinema-golem. E nada melhor do que começar por seu expoente, Der Golem, wie er in die Welt kam [O Golem: como ele veio ao mundo]. Dirigido por Carl Boese e Wegener, este "golem" é o terceiro filme de uma série concebida por Wegener, porém o único que não foi perdido.

De início, no primeiro plano do filme, nos deparamos com um céu estrelado, que será tomado, durante toda a narrativa, como a metáfora da criação do universo, e um homem que, das estruturas rochosas, observa-o constantemente, preocupado. A atmosfera criada leva-nos a pensar que tal lugar sequer existe, e o tempo, ali, não é mais contado. 
Descobrimos, na sequência seguinte, que tal homem é o rabino Loew, protetor da comunidade judaica em que morava, pois que poderia ler, através das estrelas, o destino dos homens. Assim, explica-se a cena inicial: nos céus havia lido Loew que uma tragédia aproximava-se de seu povo. O aviso desta chega mais tarde: o imperador, por meio de um decreto, obriga os judeus a deixarem a cidade (Praga), uma vez que eles "desprezam todas as cerimônias santas cristãs, colocam vidas e propriedades em risco e praticam magia negra".

Para salvar os seus da perseguição, desta forma, Loew decidirá dar vida, através de rituais e encantamentos, a uma criatura de barro, o Golem. Atingindo seu objetivo, ao escrever emet ("verdade", na língua hebraica) num papelzinho dentro do coração, ou pentagrama, do Golem, o rabino tratará de ensinar sua criatura, primeiramente, a reproduzir movimentos mecânicos e executar tarefas que nada exigiam do intelecto, como tirar a água do poço. Isso porque o Golem, um autômato, só poderia obedecer, não contestar.

Treinada sua criatura, Loew a leva até o Imperador para que um acordo pudesse ser feito: se o decreto não fosse anulado, o Golem se vingaria pelos judeus. Quando chegam à corte, então, o rabino propõe uma história. História essa que se propunha a contar a vida e os percalços enfrentados por seus patriarcas. Um único pedido foi feito antes da narrativa: que ninguém risse. Neste momento constitui-se uma das cenas mais belas, a meu ver. Por meio de montagem/colagem de fotogramas, aparece, durante a narrativa, sobreposta uma tela de formato irregular em que se representa o êxodo judeu. Magicamente as personagens do êxodo passam a interagir com os espectadores da narrativa de Loew, que, sem conseguir conter o riso, são amaldiçoados.

Esse ballet de imagens nos recorda um outro momento do filme, quando, prenunciando a catástrofe, os habitantes e religiosos da comunidade rezam pelo auxílio divino, num movimento de levantar/abaixar que, graças às sombras e luzes, nos levam a pensar que estamos diante daquele primeiro céu estrelado.

Enfim, após a reação desrespeitosa da côrte e do imperador, o Golem começa a destruir tudo o que pela frente encontra. Temeroso, o Imperador suplica ao rabino, em troca da anulação do decreto, que ele destrua o Golem. Para desativá-lo, desta maneira, o rabino apagará de emet (אמת), através da metáfora de tirar seu coração, a primeira letra da direita para a esquerda, a letra aleph ( $\aleph$ ). O que resta é met (מת), que significa morto em hebraico.

No entanto, um dos ajudantes de Loew, apaixonado pela moça que também trabalhava com o rabino e não correspondia a seu amor, decide reativar, por vingança, o 
Golem. Aliás, é interessante notar a intercalação proposital que o diretor faz entre o nascimento do Golem a partir do barro, num ambiente de angústia e desespero, e o nascimento do amor entre a jovem judia e o mensageiro da côrte, sugerindo, sutilmente, ao espectador, a incapacidade do autômato de se humanizar e, portanto, de amar.

Como consequência dessa reativação, não poderíamos ter senão uma tragédia. $\mathrm{O}$ Golem destruirá a casa do rabino, matará o mensageiro da côrte e sequestrará a jovem judia. O autômato, neste momento, parece revoltar-se com sua condição, e, não mais obedecendo a ordens, decide seguir o seu próprio rumo.

De acordo com Kracauer (1988 apud Kurtz, 2005), a temática do filme não foge, desta maneira, às expectativas do movimento expressionista. Numa primeira instância, deparamos-nos com a submissão e, em seguida, a rebelião, por parte dos judeus em relação à autoridade tirana. Em outra instância, encontramos o Golem, também submisso, agora aos judeus, e, posteriormente, rebelde.

Já em relação às expectativas visuais e técnicas pregadas pelo Expressionismo, o filme tampouco foge delas. O cenário da casa de Loew, composto por três espécies de "planos", isto é, o telhado, de onde observa as estrelas, o plano intermediário da casa em si, e o subterrâneo, onde dá vida ao Golem, parece, então, atender ao objetivo expressionista de ir ao fundo em busca da essência, do obscuro, dos possíveis reais verdadeiros. No que tange à iluminação, com a utilização da técnica chiaroscuro e com os pontos de luz que vêm, em sua maioria, de baixo e provêm apenas de fontes existentes no cenário (janelas, velas, sol etc), a fotografia que se constrói acaba por se aproximar dos quadros (pinturas) expressionistas, fornecendo uma imagem sombria e enigmática ao espectador. Da mesma forma os cortes nas cenas, acompanhando, na maioria das vezes, o olhar desviante do personagem, o esmaecimento que antecede este corte, e, posteriormente, a luz que pequena surge e cresce, e a filmagem de rostos laterais, com seus risos frios e fantasmagóricos, dão à sensação de que se está dentro de um sonho, mas um sonho que é a expressão, a realidade.

Impossível, assim, não comparar $O$ Golem ao filme de Robert Wiene, Gabinete do Dr. Caligari, outro ícone do expressionismo alemão, principalmente no que tange à estética fílmica. Já no início do filme encontramos figuras fantasmagóricas, nada "realistas", com olhos de zumbis e pele escurecida, como se doentes fossem, e cujas ações e gestos são exagerados. Também o cenário, repleto de formas geométricas distorcidas e assimétricas, foge do pretenso realismo naturalista. Aliás, até mesmo a câmera, na posição do espectador voyeur, 
fornece, por um efeito de montagem, figuras geométricas que, conforme a pretensão do momento, centralizam ou expandem a imagem de um objeto/pessoa. Como dentro de um pesadelo, já antecipando os distúrbios psicológicos ambíguos do fim do filme, o contraste entre a luz e a sombra, os ângulos irregulares, e a cenografia, composta por painéis pintados pelos expressionistas Walter Reimann e Walter Rohrig, contribuirão para o que se deu a alcunha de "caligarismo", isto é, a impressão de que uma pintura expressionista está se movimentando.

Em relação ao enredo, por fim, não podemos descartar aquilo que Benjamin tão longamente expôs à respeito dos autômatos e dos "vencedores". Neste filme, mais do que em qualquer outro, encontraríamos o poder de manipulação do Estado na comercialização cinematográfica: apenas quando seu final foi modificado, foi possível a exibição do $D r$. Caligari.

$\mathrm{Na}$ versão original, assim, Caligari, "uma autoridade ilimitada que idolatra o poder e que, para satisfazer sua avidez pela dominação, viola cruelmente todos os direitos e valores humanos" (1988 apud Bretas, 2008, p. 169), seria, no fim, responsabilizado pelas mortes executadas por Cesare, sob seu comando - e, portanto, internado em um hospital psiquiátrico: “Aqui ficava o gabinete do Doutor Caligari. Paz para suas vítimas. Paz para ele! À cidade de Holstenwall” (2000 apud Bretas 2008, p. 169). O objetivo de Janowitz e Mayer, quando escrevem sua obra "revolucionária" em meio aos traumas da Primeira Guerra seria, então, de "retratar [através da figura de Cesare] o homem comum que, sob pressão do serviço militar compulsório, é treinado para matar e ser morto" (1988 apud Bretas, 2008, p. 169).

No entanto, o filme pronto, em sua versão alterada, nos traz o Dr. Caligari lúcido, e Francis como louco, uma vez que este imagina toda a saga de um psicopata assassino, inclusive sua própria internação, como é no fim revelado ao espectador. Logo, a crítica à violência e ao delírio exercidos pelas autoridades será atenuada, e sua função social, de um certo modo, invertida. O filme, desta forma, terá sua essência subversiva descartada, e o golem, que queria se revoltar, surge apenas no imaginário de um louco, como Francis ou como o espectador - eu ou você.

\section{Referências}

BENJAMIN, Walter. Infância Berlinense. In: (Org.) PRIEUR, Jérôme. O espectador noturno: os escritores e o cinema. Tradução de Roberto Paulino. Rio de Janeiro: Nova Fronteira, 1995. 
. Obras Escolhidas: Magia e Técnica, Arte e Política. Tomo I. Tradução de Sérgio Paulo Rouanet. 3 ed. São Paulo: Brasiliense, 1987.

Teses sobre o conceito de história. In: LÖWY, Michel. Walter Benjamin: Aviso de incêndio: Uma leitura das teses "Sobre o conceito de história". Tradução de Jeanne Marie Gagnebin e Marcos Lutz Müller. São Paulo: Boitempo, 2005.

. Über den Begriff der Geschichte. Disponível em: <http://www3.culture.huberlin.de/hb/files/Benjamin_Ueber_den_Begriff_der_Geschichte.pdf $>$. Acesso em: 19 jun. 2011.

BORGES, Jorge Luis. Ficciones. Buenos Aires: Emecé, 2007.

BRETAS, Alexia. Constelação do sonho em Walter Benjamin. São Paulo: Humanitas, 2008.

CHAVES, Ernani. Considerações extemporâneas acerca das "Teses" Sobre o Conceito de História, de Walter Benjamin. Humanitas, Belém, v. 14, n. 1/2, p.19-28, 1998.

GARCIA, Janaina Pires. A arte não existe sem a técnica: relação entre arte e tecnologia. Disponível em: $<$ http://www.educacaopublica.rj.gov.br/biblioteca/educacao artistica/0040.html $>$ Acesso em: 17 nov. 2011.

KURTZ, Adriana Schryver. Golem, homunculus, robôs, andróides e cyborgs: o imaginário cinematográfico na era da cibercultura. Verso e Reverso: revista da Comunicação da Unisinos, São Leopoldo, ano 19, v. 1, n. 40, 2005. ISSN 1806-6925. Disponível em: $<$ http://www.unisinos.br/_diversos/revistas/versoereverso/index.php? $=4 \& s=9 \& a=37>$.

Acesso em: 10 nov. 2011.

LÖWY, Michel. Walter Benjamin: aviso de incêncio. Tradução de Horacio Pons. Buenos Aires: Fondo de Cultura Económica de Argentina, 2002.

NASCIMENTO, Lyslei de Souza. Golens e/ou super-brinquedos: o cinema, a tecnologia e a cabala. Aletria: revista de estudos de Literatura da UFMG, Belo Horizonte, v. 8, p. 306-309, dez. 2001. ISSN 0104-5210 Disponível em: $<$ http://www.letras.ufmg.br/poslit/08 publicacoes pgs/publicacao002108.htm $>$. Acesso em 20 nov. 2011.

SALLES, Michelle. Radiografia da metrópole carioca: registros da cidade no cinema e os paradoxos da sua imagem. 2005. 112 f. Dissertação (Mestrado em Comunicação) - Pontifícia Universidade Católica do Rio de Janeiro, Rio de Janeiro, 2005. Disponível em: <www.bocc.ubi.pt/pag/bocc-radiografia.pdf> . Acesso em: 20 nov. 2011.

SELIGMANN-SILVA. Ler o livro do mundo: Walter Benjamin: Romantismo e Crítica Poética. São Paulo: Iluminuras, 1999.

SOUSA, J. Francisco Saraiva de. Walter Benjamin: Progresso e Pobreza de Experiência. Disponível em: $\quad<$ http://cyberdemocracia.blogspot.com.br/2008/09/walter-benjaminprogresso-e-pobreza-de.html>. Acesso em: 17 nov. 2011. 
TELES, Gilberto Mendonça. Vanguarda Européia e Modernismo Brasileiro. Rio de Janeiro: Vozes, 1972.

TOMAIM, Cássio dos Santos. Cinema e Walter Benjamin: para uma vivência da descontinuidade. Estudos de Sociologia: revista de Sociologia da UNESP, Araraquara, v. 9, n. 16, p. 101-122, 2004. ISSN 1982-4718. Disponível em: $<$ http://seer.fclar.unesp.br/estudos/article/view/145>. Acesso em: 17 nov. 2011.

XAVIER, Ismail. O Discurso cinematográfico: a opacidade e a transparência. São Paulo: Paz e Terra, 1977.

\section{Filmografia}

DAS CABINET des Dr. Caligari. Direção: Robert Wiene. Berlim: Decla-Bioscop AG, 1920. 1 DVD $(78 \mathrm{~min})$.

DER GOLEM: wie er in die Welt kam. Direção: Paul Weneger e Carl Boese. Berlim: Projektions-AG Union, 1920. 1 DVD (85 min).

[Recebido em março de 2012 e aceito para publicação em junho de 2012]

\section{The Golem in the era of technical reproducibility: filmic apparatus, modern man and representation}

Abstract: Approaching Walter Benjamin to the expressionist movement in its cinematic form and its subversive attitude, this article proposes to consider the automaton's image as an allegory in the Age of Mechanical Reproduction. Thus, starting from the ideal expressionist as cinematographic technique and plot, and going through the Benjamin's Theses "On the Concept of History", as well as going through the various ideas contained in the work of the German philosopher concerning the work of art in the twentieth century, we will see the Golem, mystical character of the Jewish tradition represented by the figure of a giant, made from inanimate matter, coming to life in this text-screen. Life that has come to interrupt the course of a History which presents herself as a continuous line reporting only the history of the winners, ie, of the holders of political and / or social power, and ignoring the history of the subdued men, that is, of the until now obedient men. And such irruption should not only be the work of a mythical being, but also work of the man, as a proletarian in the capitalistic system, and of the cinematography as apparatus and representation.

Keywords: The Golem. Walter Benjamin. German Expressionism. Literature. Cinema.

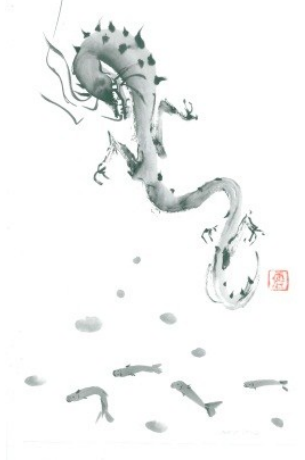

